\title{
Investigation of active species in methanation reaction over cerium based loading
}

\author{
Salmiah Jamal Mat Rosid ${ }^{a, ~ *}$, Wan Azelee Wan Abu Bakar ${ }^{b}$, Susilawati Toemen ${ }^{\mathrm{b}}$, Nurulhuda \\ Mohamad Yusoff a , Azman Azid ${ }^{c}$, Wan Nur Aini Wan Mokhtar ${ }^{d}$ \\ a UniSZa Science and Medicine Foundation Centre, Universiti Sultan Zainal Abidin, Kampus Gong Badak, 21300 Kuala Nerus, Terengganu, \\ Malaysia \\ b Department of Chemistry, Faculty of Science, Universiti Teknologi Malaysia, 81310 UTM Johor Bahru, Johor, Malaysia \\ c Faculty of Bioresources and Food Industry, Universiti Sultan Zainal Abidin, Besut Campus, 22200 Besut, Terengganu, Malaysia \\ ${ }^{d}$ Faculty of Science and Technology, Universiti Kebangsaan Malaysia, 43600 Bangi, Selangor, Malaysia
}

Corresponding author: salmiahjamal@unisza.edu.my

\section{Article history}

Received 28 December 2018

Revised 22 February 2019

Accepted 4 April 2019

Published Online 15 May 2019

Graphical abstract

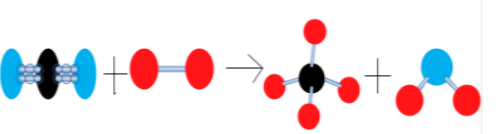

$\mathrm{CO}_{2}+\mathrm{H}_{2} \Rightarrow \mathrm{CH}_{4}+\mathrm{H}_{2} \mathrm{O}$

\begin{abstract}
A series of cerium oxide based catalyst has been studied by various cerium loadings that calcined at $1000^{\circ} \mathrm{C}$ using wet impregnation method. The potential Ru/Mn/Ce (5:35:60)/ $/ \mathrm{Al}_{2} \mathrm{O}_{3}$ catalyst calcined at $1000^{\circ} \mathrm{C}$ was characterized using XRD, XPS, and BET analyses. As could be observed from the XRD analysis, at Ce ratio of $55 \%$ and $65 \%$, both revealed the presence of $\mathrm{RuO}_{2}$ with tetragonal phase and intense, sharper peaks indicating to high crystallinity and in line with lower surface area, $50.95 \mathrm{~m} / \mathrm{g}$ in $\mathrm{BET}$ analysis. Meanwhile, $\mathrm{CeO}_{2}$ (cubic phase) and $\mathrm{MnO}_{2}$ (tetragonal phase) were also observed for $55 \%, 60 \%$, and $65 \%$, respectively. However, the presence of $\mathrm{Al}_{2} \mathrm{O}_{3}$ with rhombohedral phase at $55 \%$ and $65 \%$ was revealed as an inhibitor which decreased the $\mathrm{CO}_{2}$ conversion. The presence of active species on $\mathrm{Ru} / \mathrm{Mn} / \mathrm{Ce}(5: 35: 60) / \mathrm{Al}_{2} \mathrm{O}_{3}$ catalyst has been confirmed using XPS analysis with the deconvolation peaks belonged to $\mathrm{Ce}^{4+}$ with the formation of $\mathrm{CeO}_{2}$ compound and $\mathrm{Mn}^{4+}$ for $\mathrm{MnO}_{2}$ The product formed in catalytic methanation was proposed to be $\mathrm{H}_{2} \mathrm{O}$ and $\mathrm{CH}_{3} \mathrm{OH}$ from $\mathrm{GC}$ and HPLC analysis.
\end{abstract}

Keywords: Cerium, catalyst, carbon dioxide, methanation

\section{INTRODUCTION}

In Malaysia, urban dwellers have rapidly increased and at the same time, claims for certain types of products have been increased to meet the demands of the present society. Modern societies are relied heavily on vehicles like cars, trucks and trains. The release of the vehicle is depended primarily on the burning of fossil fuels, thereby contributing to the dominant greenhouse gases $\left(\mathrm{CO}_{2}, \mathrm{SO}_{2}, \mathrm{NO}_{2}\right)$ emitted in the air either inside or around the world. Carbon dioxide is the most important greenhouse gas generated by transport activities and it affects the global warming if its emission is not been controlled or reduced, as investigated by Yusof et al. (2010). Carbon dioxide must be eliminated to prevent or reduce harmful gases that released to the environment. This will reduce problem such as acid rain, ozone reduction, or greenhouse gases. Therefore, appropriate methods are needed to overcome this problem. Recently, alternative methods have been developed, such as the conversion of $\mathrm{CO}_{2}$ catalysts through the methanation reaction. The catalytic methanation reaction refers to the process of converting carbon monoxide and carbon dioxide from the gas stream to produce methane using catalyst (Mills and Fred, 1974). This will eliminate toxic carbon dioxide and produce methane at the same time. It is also economically viable because the catalyst is recyclable and ecologically correct, as it does not release toxic gases into the air during the reaction. As the catalytic methanation reaction has been proven to provide an excellent performance of converting $\mathrm{CO}_{2}$ in the simulated natural gas in the previous study using
$\mathrm{Ru} / \mathrm{Mn} / \mathrm{Ce}-\mathrm{Al}_{2} \mathrm{O}_{3}$ (Rosid et al., 2018a), therefore, the present study was steered in order to study the effect of based cerium, ruthenium and catalyst loading using double reactor towards catalytic activity and physicochemical properties at low reaction temperature.

\section{EXPERIMENTAL}

\section{Materials}

Chemicals used in this research were cerium(III) nitrate hexahydrate (Sigma Aldrich Chemical), ruthenium(III) chloride (Molekula), aluminium oxide (MERCK Eurolab), and manganese nitrate tetrahydrate (Sigma Aldrich Chemical).

\section{Synthesis of $\mathrm{Ru} / \mathrm{Mn} / \mathrm{Ce}$ catalyst}

Cerium salt was weighed $(5 \mathrm{~g})$ in a beaker together with manganese and ruthenium according to the desired ratio and they were dissolved in small amount of distilled water. Then, the solutions were mixed together and stirred continuously by magnetic bar for 30 minutes at room temperature to homogenize the mixture. Then, alumina beads with diameter of $3 \mathrm{~mm}$ were immersed into the catalysts solution for 20 minutes and the supported catalysts were transferred onto evaporating dish with glass wool on it. They were then aged in an oven at $80-90^{\circ} \mathrm{C}$ for 24 hours to remove water and allow good coating of the metal on the surface of the supported catalysts. They were then calcined in the furnace at $400^{\circ} \mathrm{C}$ for 5 hours under ambient atmosphere using a ramp rate of $10^{\circ} \mathrm{C} / \mathrm{min}$ to eliminate 
all the impurities, metal precursors and excess of water. The steps were repeated and applied for all different ratios of catalysts.

\section{Catalytic activity using FTIR, GC, and HPLC}

The reaction gas mixture consisting of $\mathrm{CO}_{2}$ and $\mathrm{H}_{2}$ in a 1:4 molar ratio was continuously passed through the catalyst and heated in an isothermal tubular furnace. The product stream was collected on a FTIR sample cell with attached $\mathrm{KBr}$ windows and scanned using the Nicolet Avatar 370 DTGS FTIR spectrophotometer. Gaseous products were periodically analyzed by gas chromatography to determine the formation of methane from $\mathrm{CO}_{2}$ conversion reaction. The Hewlett Packard 6890 Series gas chromatography system via flame ionization detector (FID) was set at initial temperature of $40^{\circ} \mathrm{C}$ for 7 minutes and at injection temperature of $150^{\circ} \mathrm{C}$. The presence of methanol content was observed by HPLC (Rezex ROA- organic acid) using a column of $300 \mathrm{~mm} \times 7.8 \mathrm{~mm}$ ID with Refractive Index (RI) detector with $0.005 \mathrm{~N}$ sulfuric acid as an eluent.

\section{Characterization}

In XRD analysis, the sample was manually crushed into fine powder and then placed into the sample holder. The XRD pattern was recorded by the D5000 Siemens Crystalloflex Diffractometer with $\mathrm{Cu}$ $\mathrm{K} \alpha$ radiation $(\lambda=1.54060 \AA)$. The spectrometer of XPS was flushed by using argon gas at $6 \times 10^{-9}$ Torr before putting the sample for spectrum recording to maintain sample surface integrity. Before analyzing the sample, the spectrometer was calibrated using a clean argentum crucible by assuming that the binding energy for $\mathrm{Ag} 3 d 5 / 2$ was $368.25 \mathrm{eV}$. From the spectrum, the peak for $\mathrm{C} 1 \mathrm{~s}$ was obtained at binding energy of $284.5 \mathrm{eV}$, which could be taken as the second reference. Dried powder sample was analyzed by Kratos surface analysis spectrometer XSAM HS instrument using $\mathrm{MgK} \alpha(1253.6 \mathrm{eV})$ as the X-ray source.

\section{RESULTS AND DISCUSSION}

\section{Characterization of catalyst}

Different Ce loadings revealed almost similar diffractograms, as shown in Fig. 1, where the peak was more intense and sharper, with high crystallinity. As could be observed, at ratio of $55 \%$ and $65 \%$, both showed the existence of $\mathrm{RuO}_{2}$ species with tetragonal phase. The phases detected at $55 \%$ of $\mathrm{Ce}$ loading were $\mathrm{CeO}_{2}$ (cubic), $\mathrm{Al}_{2} \mathrm{O}_{3}$ (cubic), $\mathrm{MnO}_{2}$ (tetragonal), $\mathrm{Al}_{2} \mathrm{O}_{3}$ (rhombohedral) and $\mathrm{RuO}_{2}$ (tetragonal). $\mathrm{CeO}_{2}$ with cubic phase was revealed at $2 \theta$ values of $28.48^{\circ}\left(\mathrm{I}_{100}\right), 47.43^{\circ}\left(\mathrm{I}_{45}\right), 56.40^{\circ}\left(\mathrm{I}_{33}\right), 33.33^{\circ}\left(\mathrm{I}_{27}\right), 76.20^{\circ}\left(\mathrm{I}_{10}\right)$ and $79.04^{\circ}\left(\mathrm{I}_{6}\right)$. Meanwhile, cubic $\mathrm{Al}_{2} \mathrm{O}_{3}$ was detected at $2 \theta$ values of $67.17^{\circ}\left(\mathrm{I}_{100}\right), \quad 45.43^{\circ}\left(\mathrm{I}_{100}\right), 36.82^{\circ}\left(\mathrm{I}_{90}\right)$ and $60.45^{\circ}\left(\mathrm{I}_{70}\right)$. The overlapping peaks of $\mathrm{MnO}_{2}$ with tetragonal phase were observed at $2 \theta$ value of $28.48^{\circ}\left(\mathrm{I}_{100}\right), 36.87^{\circ}\left(\mathrm{I}_{52}\right), 56.54^{\circ}$ (I $\left.\mathrm{I}_{48}\right)$, and $70.09^{\circ}$ (I $\mathrm{I}_{30}$ ) According to Wang et al. (2016), the structural characterization on unsupported and supported $\mathrm{MnO}_{\mathrm{x}}$ catalysts preferred $\mathrm{MnO}_{2}$ as an active species. Other than that, the peak of $\mathrm{RuO}_{2}$ (tetragonal) was observed to be appeared at $2 \theta$ values of $35.50^{\circ}\left(I_{77}\right), 44.12^{\circ}\left(I_{50}\right)$, and $54.86^{\circ}$ (I45). Interestingly, new peaks that assigned to corundum rhombohedral $\mathrm{Al}_{2} \mathrm{O}_{3}$ were detected at $2 \theta$ values of $35.122^{\circ}\left(\mathrm{I}_{100}\right)$, $43.317^{\circ}\left(\mathrm{I}_{96}\right), \quad 57.469^{\circ}\left(\mathrm{I}_{91}\right), 25.583^{\circ}$ ( $\left.\mathrm{I}_{68}\right)$, and $52.534\left(\mathrm{I}_{47}\right)$. As reported by Matori et al. (2012), the rhombohedral of $\mathrm{Al}_{2} \mathrm{O}_{3}$ was appeared at calcination temperature above $880^{\circ} \mathrm{C}$. The rhombohedral $\alpha-\mathrm{Al}_{2} \mathrm{O}_{3}$ is the stable phase through the nucleation and the crystallite growth process. Therefore, it was capable in increasing the particle size which then causing in a decrease of the surface area. In consequence, it would lower the catalytic activity. Similar observation was also detected for the catalyst that calcined at $1000^{\circ} \mathrm{C}$ for ratio of $65 \%$. However, in the diffractogram for ratio of $60 \%$, only $\mathrm{Al}_{2} \mathrm{O}_{3}$ cubic, $\mathrm{CeO}_{2}$ cubic and $\mathrm{MnO}_{2}$ tetragonal phase were detected. The $\mathrm{Al}_{2} \mathrm{O}_{3}$ cubic was revealed at $2 \theta$ values of $67.13^{\circ}\left(\mathrm{I}_{100}\right), 45.60^{\circ}\left(\mathrm{I}_{100}\right)$, and $36.46^{\circ}\left(\mathrm{I}_{90}\right)$, while the peak for cerium oxide cubic has been assigned at $2 \theta$ values of $28.51^{\circ}\left(\mathrm{I}_{100}\right), 47.41^{\circ}\left(\mathrm{I}_{45}\right), 56.43^{\circ}\left(\mathrm{I}_{33}\right), 33.13^{\circ}$ $\left(\mathrm{I}_{27}\right), 76.36^{\circ}\left(\mathrm{I}_{10}\right)$ and $79.02^{\circ}\left(\mathrm{I}_{6}\right)$. Meanwhile, $\mathrm{MnO}_{2}$ with tetragonal phase was observed at $2 \theta$ values of $28.56^{\circ}\left(\mathrm{I}_{100}\right), 36.98^{\circ}\left(\mathrm{I}_{52}\right)$ and $56.60^{\circ}\left(\mathrm{I}_{48}\right)$.

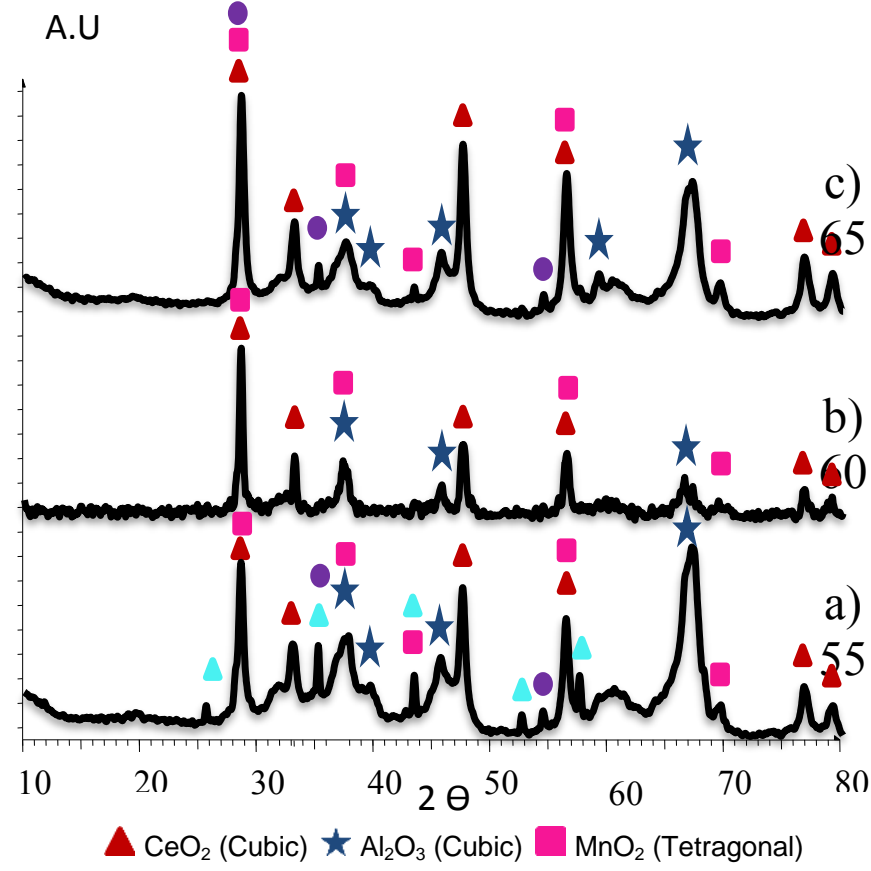

$\mathrm{RuO}_{2}$ (Tetragonal) $\triangle$ Corrundum $\mathrm{Al}_{2} \mathrm{O}_{3}$ (Rhombohedral)

Fig. 1 XRD diffraction patterns of $\mathrm{Ru} / \mathrm{Mn} / \mathrm{Ce}-\mathrm{Al}_{2} \mathrm{O}_{3}$ catalyst calcined at $1000^{\circ} \mathrm{C}$ for 5 hours with various based loadings, a) $55 \%$, b) $60 \%$ and c) $65 \%$.

XPS was used to determine the composition of the elements in the catalyst and the chemical state of the element. In this study, the charge of the specimen, the $\mathrm{C} 1 s$ line $(284.50 \mathrm{eV})$ was used as the standard. The peak of $\mathrm{Ru}$ was not detected in $\mathrm{Ru} / \mathrm{Mn} / \mathrm{Ce}(5: 35: 60) / \mathrm{Al}_{2} \mathrm{O}_{3}$ and this result was supported with XRD, in which no peak of $\mathrm{Ru}$ was observed. Fig. 2 displays the wide scan of the XPS spectrum based on the existence of different types of elements in the $\mathrm{Ru} / \mathrm{Mn} / \mathrm{Ce}$ $(5: 35: 60) / \mathrm{Al}_{2} \mathrm{O}_{3}$ catalyst sample calcined at $1000^{\circ} \mathrm{C}$.

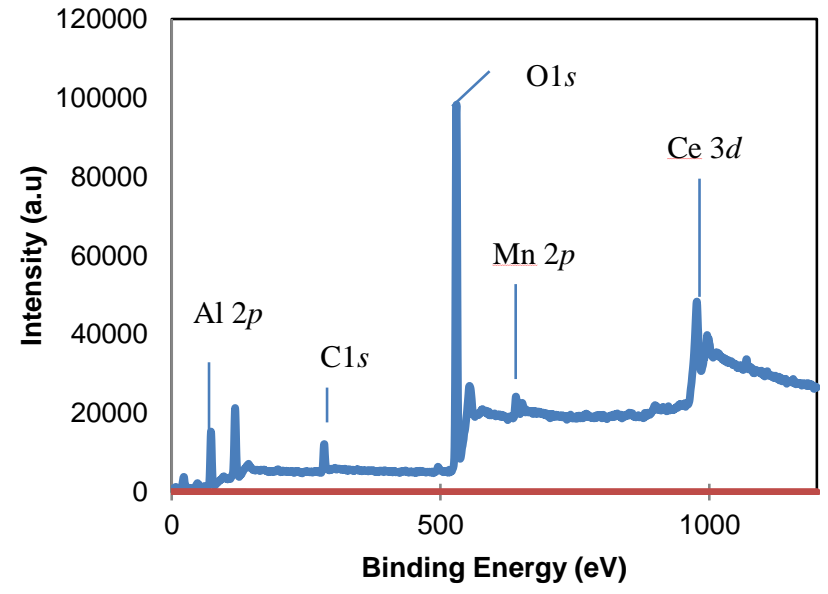

Fig. 2 Wide scan of XPS spectrum obtained from fresh $\mathrm{Ru} / \mathrm{Mn} / \mathrm{Ce}$ (5:35:60) $/ \mathrm{Al}_{2} \mathrm{O}_{3}$ catalyst calcined at $1000^{\circ} \mathrm{C}$ for 5 hours

The atomic concentration of Ce detected by XPS was low $(<0.20 \%)$, indicating the partial surface encapsulation of $\mathrm{Ce}$ and slow formation of oxygen vacancy on the alumina support, as also observed by Luches and Valeri (2015). According to XPS NIST database, the deconvolation peaks were belonged to $\mathrm{Ce}^{4+}$ with the formation of $\mathrm{CeO}_{2}$ compound, as shown in Fig. 3. Typically, Ce $3 d$ XPS core-level spectra exhibited three-lobed envelopes (around 879-890 eV, 895$910 \mathrm{eV}$ and approximately $916 \mathrm{eV}$ ). The peak of cerium was 
decomposed into six components to form two doublets. The first doublet was corresponded to Ce $3 d_{5 / 2}(E \mathrm{~b}=882.16 \mathrm{ev})$ and $\mathrm{Ce} 3 d_{5 / 2}$ $(E \mathrm{~b}=887.09 \mathrm{ev})$. The second doublet was corresponded to $\mathrm{Ce} 3 d_{3 / 2}$ $(E \mathrm{~b}=900.89 \mathrm{ev})$ and $\mathrm{Ce} 3 d_{3 / 2}(E \mathrm{~b}=904.15 \mathrm{ev})$, while the third doublet at $\mathrm{Ce} 3 \mathrm{~d}_{3 / 2}(E \mathrm{~b}=907.50 \mathrm{ev})$ and $\mathrm{Ce} 3 d_{5 / 2}(E \mathrm{~b}=884.41 \mathrm{ev})$ were attributed to cerium under its oxidized form. As could be seen, there was no systematic evolution in the positions of different peaks in which suggesting that the presence of manganese oxides did not alter the cerium chemical environments as it formed a synergistic interaction between manganese and ceria species as discussed by Liu et al. (2015). This finding was supported with XRD data where $\mathrm{CeO}_{2}$ was observed in the diffractogram (Fig. 1).

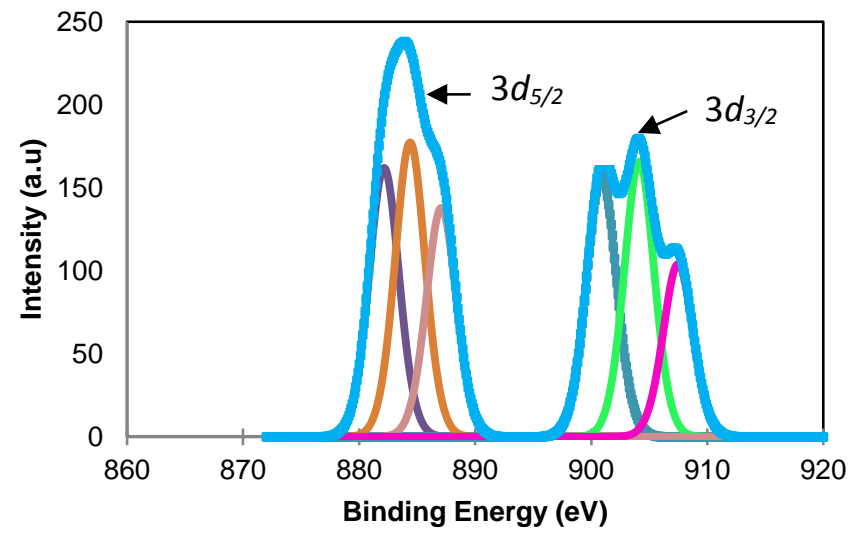

Fig. 3 High resolution $\mathrm{Ce} 3 d$ XPS spectra obtained from fresh $\mathrm{Ru} / \mathrm{Mn} / \mathrm{Ce}(5: 35: 60) / \mathrm{Al}_{2} \mathrm{O}_{3}$ catalyst calcined at $1000^{\circ} \mathrm{C}$ for 5 hours.

XPS spectra for Mn $2 p$ were consisted of two doublets as shown in Fig. 4 , which were Mn $2 p_{1 / 2}$ and $2 p_{3 / 2}$. According to literature, the binding energy, $\mathrm{Eb}$ of $\mathrm{Mn} 2 p_{3 / 2}$ in pure manganese oxides could be found at $641.2 \mathrm{eV}\left(\mathrm{Mn}^{2+}\right), 641.8 \mathrm{eV}\left(\mathrm{Mn}^{3+}\right)$, and $642.1 \mathrm{eV}\left(\mathrm{Mn}^{4+}\right)$ respectively. In this study, a compound with $\mathrm{MnO}_{2}\left(\mathrm{Mn}^{4+}\right)$ was observed at peak $E_{\mathrm{b}}$ value of $642.26 \mathrm{eV}$. This was in a good agreement with XRD analysis which $\mathrm{MnO}_{2}$ species was observed in the diffractogram. Deconvulation of $\mathrm{Mn} 2 \mathrm{p}$ produced 2 peaks at $E_{\mathrm{b}}$ value of $642.26 \mathrm{eV}$ and $644.49 \mathrm{eV}$ for $\mathrm{Mn} 2 p_{3 / 2}$, which were attributed to $\mathrm{MnO}_{2}$ species. Meanwhile for $\mathrm{Mn} 2 p_{1 / 2}, 2$ peaks at $E_{\mathrm{b}}$ value of $654.36 \mathrm{eV}$ and $656.32 \mathrm{eV}$ were also attributed to $\mathrm{MnO}_{2}$. The other two peaks with binding energy at $E_{\mathrm{b}}$ value of $641.82 \mathrm{eV}$ and $653.05 \mathrm{eV}$ were assigned to $\mathrm{Mn}_{2} \mathrm{O}_{3}$ species. However, this species was not observed in XRD analysis, which suggested that this was not an active species.

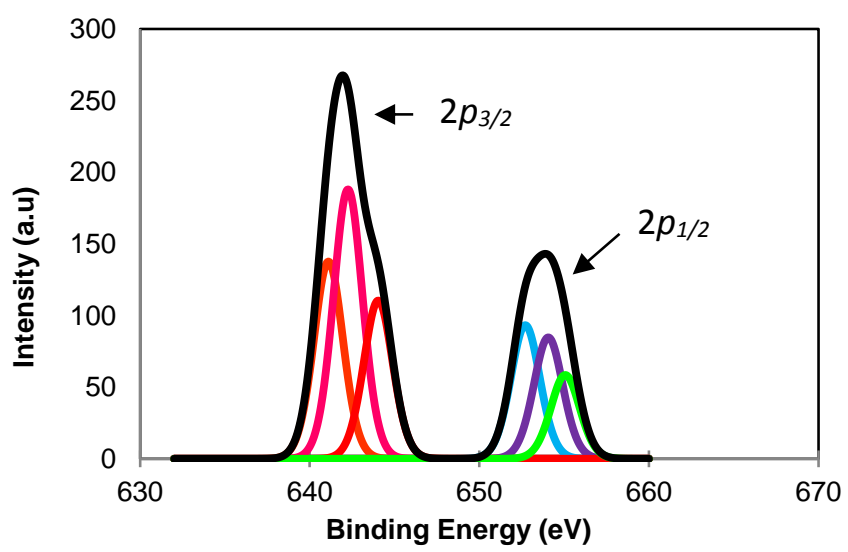

Fig. 4 High resolution Mn $2 p$ XPS spectra obtained from fresh $\mathrm{Ru} / \mathrm{Mn} / \mathrm{Ce}(5: 35: 60) / \mathrm{Al}_{2} \mathrm{O}_{3}$ catalyst calcined at $1000^{\circ} \mathrm{C}$ for 5 hours.

The BET analysis showed that when cerium loading was increased to $65 \%$, the surface area was decreased from $50.95 \mathrm{~m}^{2} / \mathrm{g}$ to $32.72 \mathrm{~m}^{2} / \mathrm{g}$ due to the removal of pores and the formation of dense solid as been discussed by Rosid et al. (2018). Therefore, it could be concluded that high surface area was important in catalytic activity since it would provide more active surfaces for catalytic interaction. The BJH pore size distribution indicated a pore diameter of around 75-120 $\mathrm{nm}$ and this was supported with smaller hysteresis. The presence of a single peak from the graph of pore size distribution in Fig. 5 was indicated to the presence of pores in the catalyst sample. The plot was corresponded to the Type IV isotherm and H3 hysteresis which consisted of aggregated or agglomerated particle in forming non-uniform slit shaped pores for the adsorption of $\mathrm{CO}_{2}$ and $\mathrm{H}_{2}$ gases as investigated by Thommes et al. (2015).
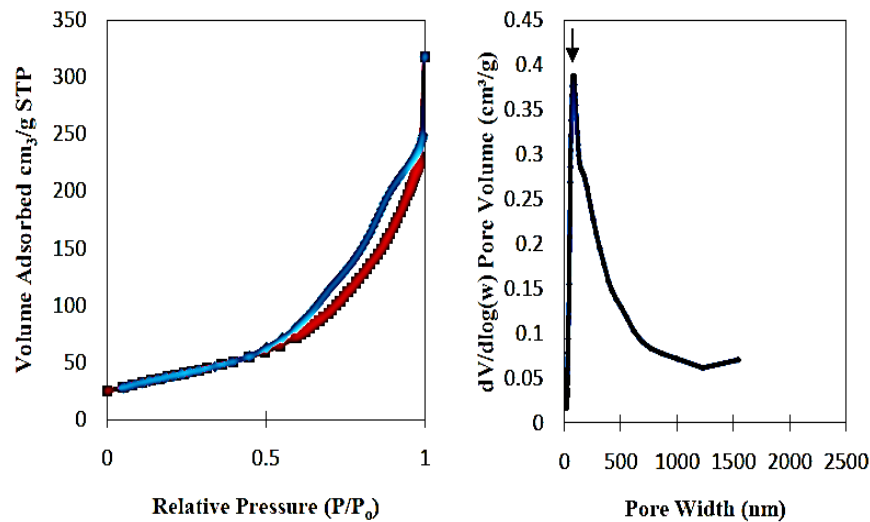

Fig. 5 Isotherm plot and pore size distribution of nitrogen adsorption for $\mathrm{Ru} / \mathrm{Mn} / \mathrm{Ce}(5: 35: 60) / \mathrm{Al}_{2} \mathrm{O}_{3}$ catalyst calcined at $1000^{\circ} \mathrm{C}$ for 5 hours.

\section{Catalytic activity of cerium oxide}

\section{Effect of various metal oxide based loadings}

The potential catalyst, $\mathrm{Ru} / \mathrm{Mn} / \mathrm{Ce}-\mathrm{Al}_{2} \mathrm{O}_{3}$ was optimized using different cerium based loadings to observe its effect on the catalytic activity. The ratios of $50-85 \mathrm{wt} \%$ of cerium oxide catalysts were selected. Fig. 6 showed that the trend plots of catalytic performance when the Ce content was increased to $60 \%$, the conversion of $\mathrm{CO}_{2}$ was increased, but it was decreased as the Ce content was up to $85 \%$. Perhaps, this was due to the blocking of surface active sites and pore structure by excessive loading of $\mathrm{Ce}$, promoting the particle to nucleate as well as inhibiting the growth of crystal (Rosid et al., 2019). Therefore, the optimum cerium loading was $60 \%$, which gave $100 \% \mathrm{CO}_{2}$ conversion.

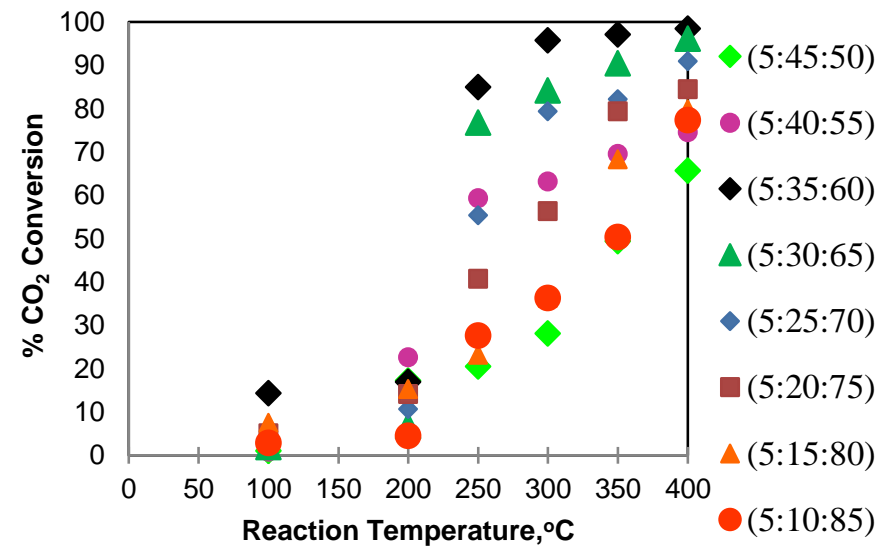

Fig. $6 \mathrm{CO}_{2}$ conversion of $\mathrm{Ru} / \mathrm{Mn} / \mathrm{Ce} / \mathrm{Al}_{2} \mathrm{O}_{3}$ catalyst calcined at $1000^{\circ} \mathrm{C}$ for 5 hours with different cerium based loadings.

\section{Effect of various ruthenium loadings}

The catalytic activities of potential catalyst with different ruthenium loadings ( $5 \mathrm{wt} \%, 10 \mathrm{wt} \%$, and $15 \mathrm{wt} \%)$ were investigated. $\mathrm{CO}_{2}$ conversion for each catalyst was started to increase significantly at $250^{\circ} \mathrm{C}$ reaction temperature. Fig. 7 showed that the $\mathrm{CO}_{2}$ conversion 
was decreased as the ruthenium loading was increased. As a result, the optimum ruthenium loadings to achieve higher $\mathrm{CO}_{2}$ conversion was 5 wt \%. This behavior might be due to an excessive distribution of ruthenium content on the support surface as suggested by Zhang et al. (2012). This finding was also in an agreement with a study conducted by Rosid et al., (2015), which stated that the addition of $5 \mathrm{wt} \%$ of ruthenium to lanthanum oxide catalyst could enhance the catalytic activity by achieving almost $100 \%$ of $\mathrm{CO}_{2}$ conversion.

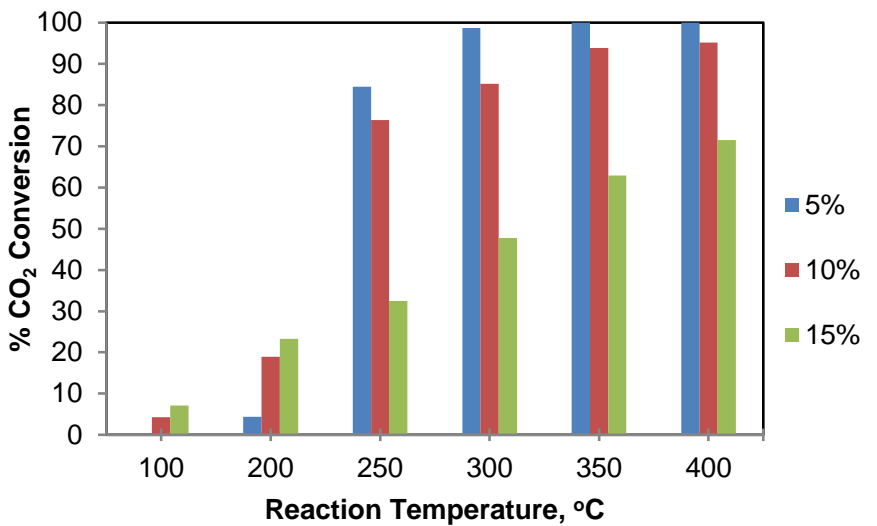

Fig. $7 \mathrm{CO}_{2}$ conversion of $\mathrm{Ru} / \mathrm{Mn} / \mathrm{Ce} / \mathrm{Al}_{2} \mathrm{O}_{3}$ catalyst calcined at $1000^{\circ} \mathrm{C}$ for 5 hours with different ruthenium loadings.

\section{Catalyst testing on $\mathrm{CO}_{2}$ methanation reaction using double reactors}

In this section, the $\mathrm{Ru} / \mathrm{Mn} / \mathrm{Ce}(5: 35: 60) / \mathrm{Al}_{2} \mathrm{O}_{3}$ catalyst was tested using two reactors instead of using one reactor, as in previous section. This testing was conducted using two isothemal furnaces connected in series. The catalyst loading was doubled in this process to examine the conversion percentage when more catalysts were utilized. Using two reactors in the catalytic activity process was also relevant in providing more time for the reaction to occur in order to maximize conversion of $\mathrm{CO}_{2}$. This method was also suitable for industrial application. Fig. 8 showed that the percentage of $\mathrm{CO}_{2}$ conversion over $\mathrm{Ru} / \mathrm{Mn} / \mathrm{Ce}(5: 35: 60) / \mathrm{Al}_{2} \mathrm{O}_{3}$ catalyst calcined at $1000^{\circ} \mathrm{C}$ by double reactor was $95.83 \%$ at $350^{\circ} \mathrm{C}$ reaction temperature. The performance of the catalyst was slightly lower compared to single reactor over the same catalyst that achieved $100 \%$ at the same reaction temperature. The findings by Li et al., (2014) were in agreement with our results that stated the decrease of $\mathrm{CO}_{2}$ conversion in the second reactor might be caused by the formation of water in the first reactor at low temperature which blocked the catalyst surface during reaction at the first reactor.

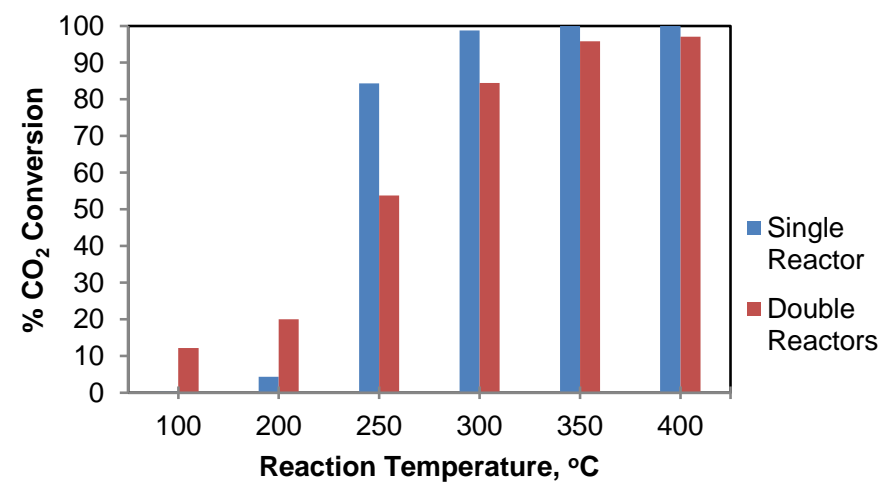

Fig. $8 \mathrm{CO}_{2}$ conversion of $\mathrm{Ru} / \mathrm{Mn} / \mathrm{Ce}(5: 35: 60) / \mathrm{Al}_{2} \mathrm{O}_{3}$ catalyst calcined at $1000^{\circ} \mathrm{C}$ for 5 hours with double reactor.

\section{Methane formation by gas chromatography}

The $\mathrm{Ru} / \mathrm{Mn} / \mathrm{Ce}-\mathrm{Al}_{2} \mathrm{O}_{3}$ catalyst was further investigated to determine the production of methane by GC analysis. The results showed that no methane product was formed at initial reaction temperatures of $100^{\circ} \mathrm{C}$ and $200^{\circ} \mathrm{C}$. As the reaction temperatures were raised up to $300^{\circ} \mathrm{C}, 350^{\circ} \mathrm{C}$, and $400^{\circ} \mathrm{C}$, about $40.71 \%, 66.80 \%$ and $78.00 \%$ of methane were formed respectively at $1000^{\circ} \mathrm{C}$ of calcination temperature. Meanwhile, for $\mathrm{Ru} / \mathrm{Mn} / \mathrm{Ce} \quad(5: 40: 55) / \mathrm{Al}_{2} \mathrm{O}_{3}$ and $\mathrm{Ru} / \mathrm{Mn} / \mathrm{Ce}(5: 30: 65) / \mathrm{Al}_{2} \mathrm{O}_{3}$, the methane products that formed were $35.54 \%$ and $42.87 \%$, respectively at $400^{\circ} \mathrm{C}$ of reaction temperature. The results showed that $\mathrm{Ru} / \mathrm{Mn} / \mathrm{Ce}(5: 35: 60) / \mathrm{Al}_{2} \mathrm{O}_{3}$ calcined at $1000^{\circ} \mathrm{C}$ was assigned as the potential catalyst among other studied cerium catalysts due to high methane formation. High methane formation achieved at high reaction temperatures might be due to high exothermic reactions where the methane reaction was favored at high temperatures.

\section{Detection of methanol by high performance liquid chromatography (HPLC)}

The methane formation which detected by GC using a single reactor for this potential catalyst was far from the value of $\mathrm{CO}_{2}$ conversion. Therefore, HPLC tests were conducted to confirm the presence of methanol as a side product. The HPLC analysis illustrated that the compound of interest was eluted at retention time of $20 \mathrm{~min}$ for standard methanol. When the sample was injected, peaks were started to appear at $20 \mathrm{~min}$ of retention and assigned to methanol compound as it was compatible with standard methanol (not shown).

\section{CONCLUSION}

The potential $\mathrm{Ru} / \mathrm{Mn} / \mathrm{Ce}(5: 35: 60)-\mathrm{Al}_{2} \mathrm{O}_{3}$ catalysts with various based cerium, ruthenium, and catalyst loadings have shown an effect towards catalytic activity and physicochemical properties. The percentages of $\mathrm{CO}_{2}$ conversion for $\mathrm{Ru} / \mathrm{Mn} / \mathrm{Ce}(5: 40: 55)-\mathrm{Al}_{2} \mathrm{O}_{3}$, $\mathrm{Ru} / \mathrm{Mn} / \mathrm{Ce}(5: 35: 60)-\mathrm{Al}_{2} \mathrm{O}_{3}$, and $\mathrm{Ru} / \mathrm{Mn} / \mathrm{Ce}(5: 30: 65)-\mathrm{Al}_{2} \mathrm{O}_{3}$ were $74.53 \%, 100 \%$ and $96.12 \%$, respectively at $400^{\circ} \mathrm{C}$ of reaction temperature. The products of this reaction were confirmed to be $\mathrm{H}_{2} \mathrm{O}$, $\mathrm{CH}_{4}$ and $\mathrm{CH}_{3} \mathrm{OH}$. The XRD analysis revealed that the active species in the potential catalyst were $\mathrm{CeO}_{2}$ and $\mathrm{MnO}_{2}$, meanwhile corruncum rhombohedral $\mathrm{Al}_{2} \mathrm{O}_{3}$ was assigned as an inhibitor species at $55 \%$ and $65 \%$ cerium loading. The presence of active species was supported with XPS analysis and BET analysis showed that the surface area was lower for $55 \%$ and $65 \%$ with $27.23 \mathrm{~m}^{2} / \mathrm{g}$ and $32.72 \mathrm{~m}^{2} / \mathrm{g}$, respectively.

\section{ACKNOWLEDGEMENT}

The authors would like to thank to Universiti Sultan Zainal Abidin, Universiti Teknologi Malaysia and Ministry of Higher Education (MOHE), Malaysia for financial support.

\section{REFERENCES}

Li C. Yuan X. and Fujimoto K. 2014. Development of highly stable catalyst for methanol synthesis from carbon dioxide. Applied Catalysis A: General 469, 306-311.

Liu L. Shi J. Zhang X. Liu J. Z. 2015. Flower like Mn-doped $\mathrm{CeO}_{2}$ microstructure: Synthesis, characterization and catalytic properties. Journal of Chemistry, Article ID 254750. 1-11.

Luches P. and Valeri S. 2015. Structure, morphology and reducibility of epitaxial cerium oxide ultrathin films and nanostructures. Materials (Basel) 8(9), 5818-5833.

Matori K. A. Wah L. C. Hashim M. Ismail I. and Zaid M. H. M. 2012. Phase transformation of alumina made from waste aluminium via a precipitation technique. International Journal of Molecular Science 13(12), 16812 16821.

Mills G. A. and Fred W. S. 1974. Catalytic methanation. Catalysis Review: Science and Engineering 8(1), 159-210.

Rosid, S. J. M, Bakar, W. A. W. A. and Ali, R. 2015. Physicochemical study of supported cobalt-lanthanum oxide based catalysts for $\mathrm{CO}_{2} / \mathrm{H}_{2}$ methanation reaction. Clean Technology Environmental Policy, 17(1), 257-264.

Rosid, S. J. M, Bakar, W. A. W. A. and Ali, R. 2018. Characterization and modelling optimization on methanation activity using Box-Behnken design through cerium doped catalysts. Journal of Cleaner Production. 170. 278-287

Rosid, S. J. M., Toemen, S., Bakar, W. A. W. A., Zamani, A. H., and Mokhtar W. N. A. W. 2019. Physicochemical characteristic of neodymium oxide- 
based catalyst for in-situ $\mathrm{CO}_{2} / \mathrm{H}_{2}$ methanation reaction. Journal of Saudi Chemical Society. 23, 284-293.

Thommes, M., Kaneko, K., Neimark, A. V., Oliver, J. P., Rodrigue-Reinoso, F., Ronquerol, J., and Sing, K. S. W. 2015. Physisorption of gases, with special reference to the evaluation of surface area and pore size distribution (IUPAC Technical Report). Pure and Applied Chemistry 87(910). 1051-1069.

Wang, L., He, H., Zhang, C., Wang, Y., and Zhang, B. 2016. Effect of precursors for manganese loaded $\gamma-\mathrm{Al}_{2} \mathrm{O}_{3}$ catlaysts on plasma-catalytic removal of o-xylene. Chemical Engineering Journal 288(C), 406-413.
Yusof, N. B. M., Mohamad, F. I, Ruslan, H. 2010. Estimation of dispersion of carbon monoxide $(\mathrm{CO})$, nitrogen dioxide $\left(\mathrm{NO}_{2}\right)$, and carbon dioxide $\left(\mathrm{CO}_{2}\right)$ from Port Klang - KLIA Road. Universiti Teknologi Nasional, Malaysia.

Zhang, Y. F., Zhang, G., Wang, L., Xu, Y., Sun, Y. 2012. Selective methanation of carbon monoxide over $\mathrm{Ru}$ based catalysts in $\mathrm{H}_{2}$-rich gases. Journal of Industrial and Engineering Chemistry 18(5), 1590-1597. 